\title{
Angiotensin II Stimulates Protein-Tyrosine Phosphorylation in a Calcium-Dependent Manner
}

\author{
WILLIAM R. HUCKLE, ${ }^{1}$ CAROL A. PROKOP,${ }^{1}$ RUTH C. DY, ${ }^{1}$ BRIAN HERMAN,${ }^{1,2}$ \\ AND SHELTON EARP ${ }^{1.3 *}$ \\ Cell Biology Program of the Lineberger Cancer Research Center ${ }^{1}$ and Departments of Medicine \\ and Pharmacology, ${ }^{3}$ and Department of Cell Biology and Anatomy, ${ }^{2}$ School of Medicine, \\ University of North Carolina at Chapel Hill, Chapel Hill, North Carolina 27599-7295
}

Received 16 June 1990/Accepted 24 August 1990

\begin{abstract}
Cellular responses to epidermal growth factor (EGF) are dependent on the tyrosine-specific protein kinase activity of the cell-surface EGF receptor. Previous studies using WB rat liver epithelial cells have detected at least 10 proteins whose phosphotyrosine (P-Tyr) content is increased by EGF. In this study, we have examined alternate modes of activating tyrosine phosphorylation. Treatment of WB cells with hormones linked to $\mathrm{Ca}^{2+}$ mobilization and protein kinase C (PKC) activation, including angiotensin II, [Arg ${ }^{8}$ ]vasopressin, or epinephrine, stimulated rapid $(\leq 15-\mathrm{s})$ and transient increases in the $P-T y r$ content of several proteins (p120/125, p75/78, and p66). These proteins, detected by anti-P-Tyr immunoblotting, were similar in molecular weight to a subset of EGF-sensitive P-Tyr-containing proteins (P-Tyr-proteins). The increased P-Tyr content was confirmed by $\left[{ }^{32} \mathrm{P}\right]$ phosphoamino acid analysis of proteins recovered by anti-P-Tyr immunoprecipitation. Elevating intracellular $\left[\mathrm{Ca}^{2+}\right]$ with the ionophore $\mathrm{A} 23187$ or ionomycin or with the tumor promoter thapsigargin mimicked the effects of hormones on tyrosine phosphorylation, whereas treatment with a PKC-activating phorbol ester did not. In addition, responses to angiotensin II were not diminished in PKC-depleted cells. $\mathrm{Ca}^{2+}$ mobilization, measured by fura-2 fluorescence, was coincident with the increase in tyrosine phosphorylation in response to angiotensin II or thapsigargin. Loading cells with the intracellular $\mathrm{Ca}^{2+}$ chelator bis-(O-aminophenoxy)ethane- $N, N, N^{\prime}, N^{\prime}$-tetraacetic acid (BAPTA) inhibited the appearance of all P-Tyr-proteins in response to angiotensin II, thapsigargin, or ionophores, as well as two EGF-stimulated P-Tyr-proteins. The majority of EGF-stimulated P-Tyr-proteins were not affected by BAPTA. These studies indicate that angiotensin II can alter protein-tyrosine phosphorylation in a manner that is secondary to, and apparently dependent on, $\mathrm{Ca}^{2+}$ mobilization. Thus, ligands such as EGF and angiotensin II, which act through distinct types of receptors, may activate secondary pathways involving tyrosine phosphorylation. These results also raise the possibility that certain growth-promoting effects of $\mathrm{Ca}^{2+}$-mobilizing agents such as angiotensin II may be mediated via tyrosine phosphorylation.
\end{abstract}

Reversible phosphorylation of proteins is a major mechanism by which metabolic processes are regulated. Phosphorylation on serine and threonine residues, which together account for $>99 \%$ of total cellular protein phosphate, are recognized as key elements in the regulation of such diverse pathways as glycogen metabolism, protein biosynthesis, and cell surface receptor signaling (19). Phosphorylation on tyrosine residues, which accounts for $<0.5 \%$ of proteinbound phosphate (12), has been linked broadly with the control of cell proliferation. Receptors for several growth factors, including epidermal growth factor (EGF) and platelet-derived growth factor, contain ligand-activated, tyrosinespecific protein kinase domains essential for biological activity $(76,78)$. Similarly, the protein products of several oncogenes (e.g., src and $a b l$ ) exhibit tyrosine kinase activities essential for oncogenic transformation $(36,41)$.

The identities of relevant substrates for tyrosine kinases remain largely obscure because of the technical challenge of monitoring transient tyrosine phosphorylation events against high backgrounds of serine/threonine phosphorylation and because of the complex and temporally protracted nature of mitogenesis. Nevertheless, several potential substrates for tyrosine kinases in intact cells have been identified, using combinations of ${ }^{32} \mathrm{P}$ labeling, electrophoresis, phosphoami-

\footnotetext{
* Corresponding author.
}

no acid analysis, and immunoprecipitation and immunoblotting with antiphosphotyrosine (anti-P-Tyr) antibodies. One group of substrates are structural proteins, including vinculin, the fibronectin receptor, ezrin, and calpactins I and II (reviewed in reference 9). Several proteins likely to propagate acute growth factor receptor signals also have been identified as tyrosine kinase substrates: phosphatidylinositol kinase, phosphoinositide (PtdIns)-specific phospholipase $\mathrm{C}-\gamma(\mathrm{PLC} \gamma)$, the ras GTPase-activating protein, and the serine/threonine kinases Raf-1 and microtubule-associated protein 2 (MAP-2) kinase $(56,76)$.

Our laboratory has studied the regulation of EGF signalling in the nontransformed rat liver epithelial cell line WB (71), which expresses EGF receptors at levels $\left(2 \times 10^{5}\right.$ to 3 $\times 10^{5}$ per cell) comparable to those in hepatocytes. Exposure of WB cells to EGF provokes a cascade of events: EGF receptor tyrosine autophosphorylation and phosphorylation of other cellular proteins $(\leq 5 \mathrm{~s})$; production of $\mathrm{Ca}^{2+}$-mobilizing inositol phosphates, activation of protein kinase $\mathrm{C}$ (PKC), and receptor internalization (1 to $2 \mathrm{~min}$ ) and, after a period of hours, protein and DNA synthesis $(38,49,71)$. These cells also express receptors for several hormones (e.g., angiotensin II, [Arg ${ }^{8}$ ]vasopressin, and epinephrine) whose actions are believed to be mediated by non-tyrosine kinase-containing receptors coupled principally to $\mathrm{Ca}^{2+}$ mobilization and PKC activation. These hormones increase EGF receptor mRNA and protein levels by a mechanism 
partly independent of PKC (18). Activation of PKC by phorbol esters can inhibit EGF-stimulated PtdIns hydrolysis (38), EGF receptor kinase activity, and tyrosine phosphorylation of PLC $\gamma$ in WB cells (W. R. Huckle, J. R. Hepler, S. G. Rhee, T. K. Harden, and H. S. Earp, Endocrinology, in press); phorbol ester treatment likewise can uncouple angiotensin II receptors from ligand-stimulated PtdIns hydrolysis (38). While investigating possible heterologous desensitization of the EGF receptor kinase by other PKCactivating agonists in WB cells, we noted that angiotensin II itself stimulated increases in the tyrosine phosphorylation of several proteins. In this work, we report this effect and present evidence that it is dependent on increases in cytosolic $\mathrm{Ca}^{2+}$ levels. These findings indicate that hormone receptors not thought to possess intrinsic tyrosine kinase activity may nonetheless signal through tyrosine phosphorylation and suggest a mechanism by which their ligands elicit effects similar to those of recognized growth factors.

\section{MATERIALS AND METHODS}

Materials. EGF was purified from mouse salivary glands as described previously (58). Human sequence angiotensin II (Asp Arg Val Tyr Ile His Pro Phe), [Arg ${ }^{8}$ ]vasopressin, (-)-epinephrine (Sigma), and EGF were prepared as 100fold-concentrated solutions in $10 \mathrm{mM} \mathrm{NaP}-150 \mathrm{mM} \mathrm{NaCl}$ (pH 7.4) containing $0.1 \%$ bovine serum albumin. Phorbol 12-myristate 13-acetate (PMA; Sigma), thapsigargin (LC Services), bis-( $O$-aminophenoxy)ethane- $N, N, N^{\prime}, N^{\prime}$-tetraacetic acid, tetraacetoxymethyl ester (BAPTA-AM; GIBCOBRL), ionomycin, A23187 (Calbiochem), and fura-2, tetraacetoxymethyl ester (fura-2-AM; Molecular Probes) were prepared as stock solutions in dimethyl sulfoxide; final vehicle concentration was $\leq \mathbf{0 . 1 \%}(\mathrm{vol} / \mathrm{vol})$. Polyclonal antiP-Tyr antibodies were prepared as described previously (49) except that affinity purification was performed by chromatography on immobilized phosphotyramine.

Cell cultures. WB cells were maintained at $37^{\circ} \mathrm{C}$ in Richter improved minimal essential medium containing $10 \%$ fetal bovine serum and $0.1 \mu \mathrm{M}$ insulin in a humidified $5 \% \mathrm{CO}_{2}$ atmosphere as described previously (38). Seven to ten days before each experiment, cells of passages 19 to 26 were seeded onto plastic culture dishes (Costar) or glass cover slips (Fisher). Except where indicated, cells were used for experiments 1 to 2 days after reaching confluence. Before addition of EGF, angiotensin II, or other agents, cells were washed once with Eagle minimal essential medium containing $20 \mathrm{mM} N$-2-hydroxyethylpiperazine- $N^{\prime}$-2-ethanesulfonic acid (EMEM-HEPES, pH 7.3) and were allowed to equilibrate in this medium for $15 \mathrm{~min}$ at $37^{\circ} \mathrm{C}$.

Anti-P-Tyr immunoblotting. Cell treatments and anti-PTyr immunoblotting were performed essentially as described previously (49), using WB cells grown in 35-mm-diameter culture dishes. Briefly, treatment incubations were terminated by rapid aspiration of the medium and addition of 250 $\mu l$ ice-cold RIPA buffer (49). Cell extracts were scraped from culture dishes and solubilized by addition of $125 \mu \mathrm{l}$ of threefold-concentrated sodium dodecyl sulfate (SDS)-polyacrylamide gel electrophoresis (PAGE) sample buffer and heating to $100^{\circ} \mathrm{C}$ for $3 \mathrm{~min}$. Proteins were separated by electrophoresis on 7 or $10 \%$ polyacrylamide gels and transferred to nitrocellulose membranes. Blots were probed by sequential incubation with affinity-purified anti-P-Tyr antibodies and ${ }^{125} \mathrm{I}$-protein $\mathrm{A}$ (2 to $10 \mu \mathrm{Ci} / \mu \mathrm{g}$; Dupont-New England Nuclear), followed by autoradiography. Molecular weights of P-Tyr-containing proteins (P-Tyr-proteins) were estimated by using prestained standards calibrated by comparison with the migration of nonprestained standards (Sigma). Relative intensities of autoradiographic bands were estimated by scanning densitometry (LKB Ultroscan XL). The appearance of all autoradiographic bands could be completely blocked by addition of $1 \mathrm{mM}$ phenylphosphate or P-Tyr during the antibody incubation. In some experiments, blots were probed with monoclonal anti-P-Tyr antibody PY20 (29) (1 $\mu \mathrm{g} / \mathrm{ml}$; ICN ImmunoBiologicals), followed by rabbit anti-mouse immunoglobulin $G(1 \mu \mathrm{g} / \mathrm{ml}$; Jackson ImmunoResearch) and ${ }^{125}$ I-protein A.

Phosphoamino acid analysis. Confluent WB cell cultures in 60-mm-diameter dishes were prelabeled by incubation $(2 \mathrm{~h}$, $37^{\circ} \mathrm{C}$ ) with $1 \mathrm{mCi}$ of $\mathrm{H}_{3}{ }^{32} \mathrm{PO}_{4}(>8,500 \mathrm{Ci} / \mathrm{mmol}$; Dupont-New England Nuclear) in $3 \mathrm{ml}$ of phosphate-free EMEM-HEPES supplemented with $0.5 \%$ fetal bovine serum. After treatment with EGF or other agents, the medium was aspirated, and cells were scraped from the dishes in $0.3 \mathrm{ml}$ of ice-cold lysis buffer (20 mM HEPES [pH 7.3], $50 \mathrm{mM} \mathrm{NaF}, 10 \%$ [vol/vol] glycerol, $1 \%$ [wt/vol] Triton $\mathrm{X}-100,1 \mathrm{mM}$ sodium $o$-vanadate, $10 \mu \mathrm{g}$ of phenylmethylsulfonyl fluoride per ml). Lysates were tumbled for $30 \mathrm{~min}$ at $4^{\circ} \mathrm{C}$ and then centrifuged at $12,000 \times g$ for $15 \mathrm{~min}$ at $4^{\circ} \mathrm{C}$. Supernatants were transferred to conical $15-\mathrm{ml}$ polypropylene tubes, brought to $1 \%$ SDS and $100 \mathrm{mM} 2$-mercaptoethanol, and heated to $100^{\circ} \mathrm{C}$ for 5 min. Samples were chilled on ice and diluted to $3 \mathrm{ml}$ with lysis buffer. P-Tyr-proteins were immunoprecipitated by incubation $\left(2 \mathrm{~h}, 4^{\circ} \mathrm{C}\right)$ with $1 \mu \mathrm{g}$ of monoclonal anti-P-Tyr antibody PY20, $5 \mu \mathrm{g}$ of rabbit anti-mouse immunoglobulin $\mathrm{G}$, and $10 \mu \mathrm{l}$ of Pansorbin (Calbiochem). Immunoprecipitates were recovered by centrifugation and washed by sequential suspension and centrifugation in lysis buffer plus (i) $0.1 \% \mathrm{SDS}$, (ii) $0.5 \mathrm{M} \mathrm{NaCl}$, and (iii) $0.1 \%$ SDS. Immunoprecipitates then were solubilized for SDS-PAGE on $7 \%$ polyacrylamide gels. Phosphoproteins were transferred to Immobilon membranes and were located by autoradiography. Bands of interest were excised from the Immobilon blot and subjected to acid hydrolysis (43), two-dimensional electrophoresis (12), and autoradiography.

Measurement of intracellular $\mathrm{Ca}^{2+}$. Calcium monitoring was performed essentially as described previously (77). WB cells were grown on 22-by-22-mm glass cover slips to approximately $80 \%$ confluence. Cells were chilled to $4^{\circ} \mathrm{C}$ for 5 min in EMEM-HEPES and then loaded with the fluorescent $\mathrm{Ca}^{2+}$ indicator fura-2 (34) by incubation with $5 \mu \mathrm{M}$ fura2-AM for 15 min at $37^{\circ} \mathrm{C}$. After three washes with EMEMHEPES, the cover slips were mounted on the stage of a digital video fluorescence microscope. Fluorescence (340and $380-\mathrm{nm}$ excitation; $>440-\mathrm{nm}$ emission) was monitored at 15- to 30-s intervals before and after treatment of cells with angiotensin II or thapsigargin. Free $\left[\mathrm{Ca}^{2+}\right]$ was calculated by the ratio method, with correction for background fluorescence (80).

\section{RESULTS}

Angiotensin II and [Arg ${ }^{8}$ vasopressin increase protein-tyrosine phosphorylation in WB cells. As reported previously (49), EGF stimulated rapid ( $\leq 5-s)$ increases in the tyrosine phosphorylation of several proteins, the most prominent being the 170-kDa EGF receptor (Fig. 1). Treatment with angiotensin II provoked increases in the tyrosine phosphorylation of several species similar in molecular weight to those affected by EGF: p120/125, p75/78, and p66 (Fig. 1). On shorter autoradiographic exposures, the species of $120 /$ 125 and 75/78 kDa could be resolved as doublet bands (Fig. 


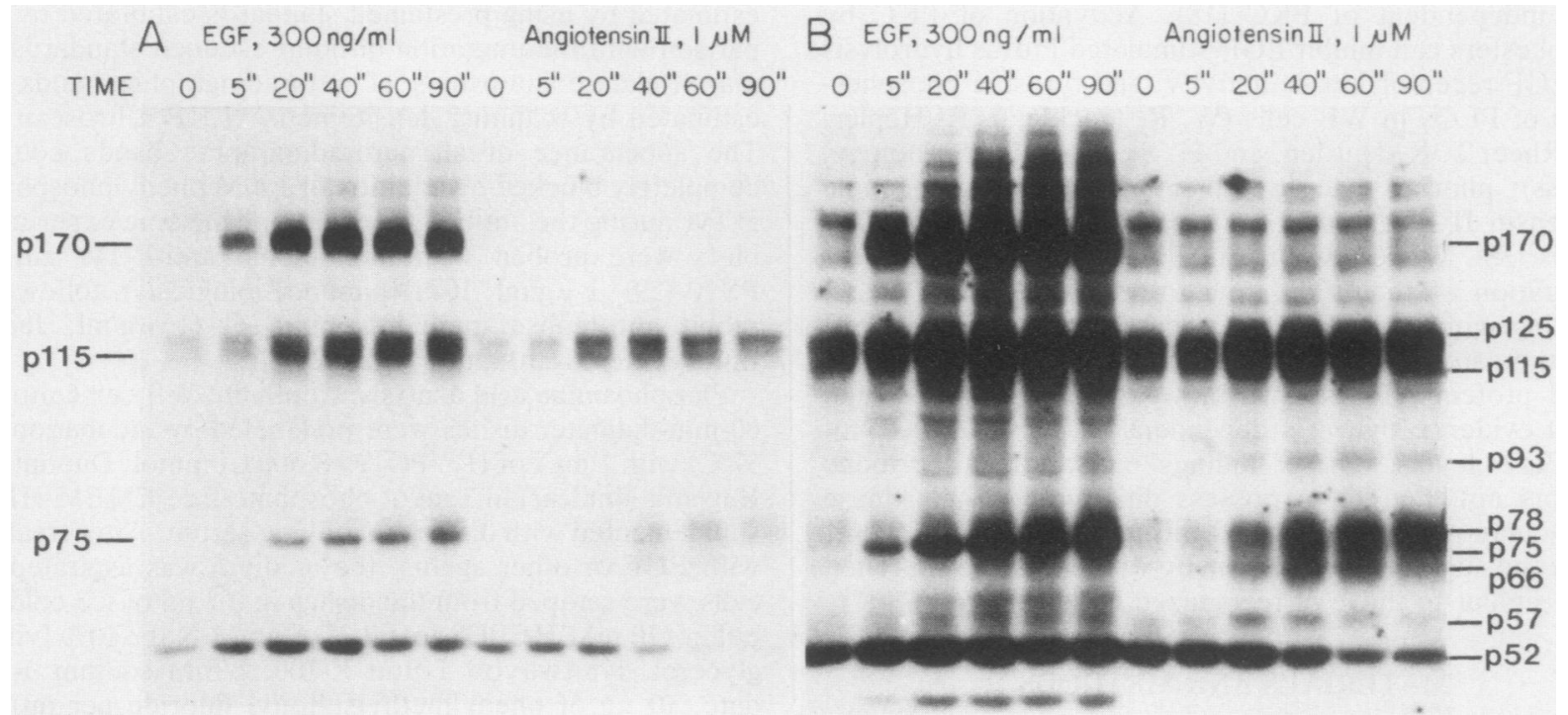

FIG. 1. EGF- and angiotensin II-stimulated tyrosine phosphorylation. WB cells were treated with EGF ( $300 \mathrm{ng} / \mathrm{ml})$ or angiotensin II (1 $\mu \mathrm{M}$ ) for the times indicated (in seconds), and tyrosine phosphorylation was assessed by anti-P-Tyr immunoblotting after SDS-PAGE on 7\% polyacrylamide gels as described in Materials and Methods. Autoradiographs shown (representative of three separate experiments) were exposed for $2(\mathrm{~A})$ or $6(\mathrm{~B})$ days at $-70^{\circ} \mathrm{C}$.

1A). Angiotensin II-stimulated increases in less prominent species, P-Tyr-p57, -p93, and -p115, were evident upon longer autoradiographic exposures (Fig. 1B). Similar patterns of tyrosine phosphorylation were observed when blots were probed with either purified polyclonal anti-P-Tyr antibodies or monoclonal antibody PY20 (not shown). The response to angiotensin II was both rapid and transient, with maximal increases in P-Tyr-p66, -p75/78, and -p120/125 occurring between 30 and $60 \mathrm{~s}$ of treatment. Phosphorylation of the p75/78 doublet persisted above basal levels for $>5$ min, although an increase in the intensity of the upper band, and concomitant decrease in the intensity of the lower band, occurred over $5 \mathrm{~min}$ of treatment. In contrast, increased P-Tyr-p66 was no longer detected after 2 min of angiotensin II treatment. Elevated tyrosine phosphorylation was detectable at angiotensin II concentrations as low as $1 \mathrm{nM}$; the angiotensin II effects could be blocked by the receptor antagonist [ $\mathrm{Sar}^{1}, \mathrm{Val}^{5}, \mathrm{Ala}^{8}$ ]angiotensin.

Although both EGF and angiotensin II affected the tyrosine phosphorylation of several proteins similar in molecular weight (p57, p66, p75/78, p93, and p120/125), other species ( $\mathrm{p} 170 / \mathrm{EGF}$ receptor, $\mathrm{p} 59$, and $\mathrm{p} 40$ ) were unique to EGF-treated cells. Similarly, PLC $\gamma$ is phosphorylated on tyrosine in response to EGF but not angiotensin II (38a). Initial attempts to separate EGF- and angiotensin II-dependent substrates into cytosolic and membrane fractions by conventional procedures were complicated by rapid losses of P-Tyr, even in the presence of phosphatase inhibitors. Homogenization and fractionation at $\mathrm{pH} 9.5$, however, inhibited loss of P-Tyr from EGF- and angiotensin II-sensitive proteins and revealed that all angiotensin II-stimulated bands, as well as the EGF-sensitive bands of similar molecular weight (p120, p75, and p66), partitioned into the supernatant fraction $(105,000 \times g ;$ W. R. Huckle, C. A. Prokop, and H. S. Earp, unpublished results).

Treatment of WB cells with another peptide hormone, [Arg ${ }^{8}$ ]vasopressin (Fig. 2), or with the adrenergic receptor agonist epinephrine (not shown) produced increases in tyrosine phosphorylation similar to that seen in response to angiotensin II. This effect of epinephrine was not obtained with the $\beta$-adrenergic receptor-selective agonist isoproterenol or with the membrane-permeant compound dibutyryl cyclic AMP (Huckle et al., unpublished results).

Increases in cytosolic calcium mimic the effects of angiotensin II on tyrosine phosphorylation. Activation of the angiotensin receptor is recognized to produce $\mathrm{PKC}$-activating diacylglycerols and $\mathrm{Ca}^{2+}$-mobilizing inositol phosphates. To test the role of cytosolic $\mathrm{Ca}^{2+}$ in the angiotensin II-stimulated increase in tyrosine phosphorylation, WB cells were treated with other agents that increase intracellular $\mathrm{Ca}^{2+}$ levels (Fig. 3). The tumor promoter thapsigargin (67), which

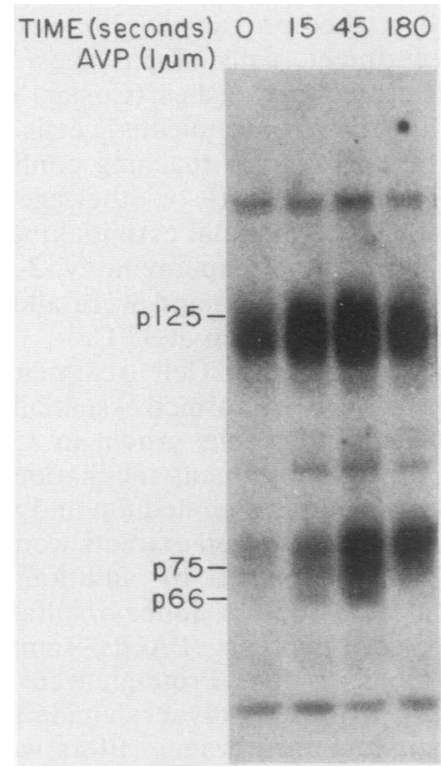

FIG. 2. $\left[\mathrm{Arg}^{8}\right.$ ]vasopressin-stimulated increase in tyrosine phosphorylation. WB cells were treated with $1 \mu \mathrm{M}\left[\mathrm{Arg}^{8}\right]$ vasopressin (AVP) for the times indicated; tyrosine phosphorylation then was assessed by immunoblotting as described in Materials and Methods. 


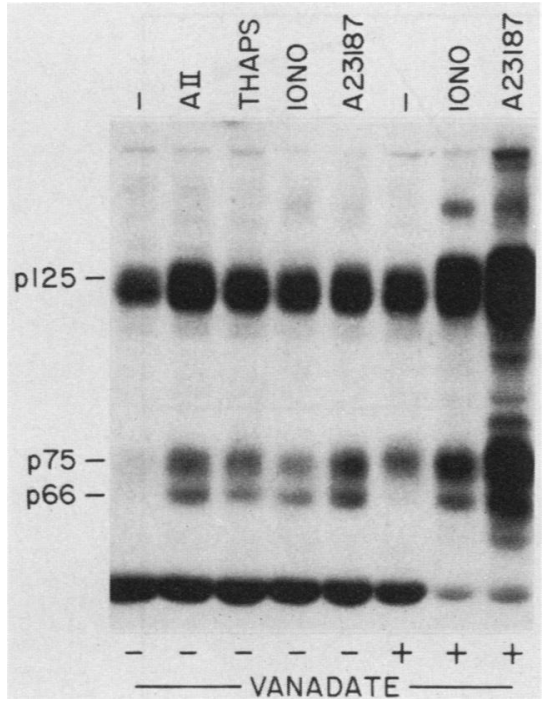

FIG. 3. Effects of $\mathrm{Ca}^{2+}$-elevating agents on WB cell tyrosine phosphorylation. WB cells were treated with various $\mathrm{Ca}^{2+}$-mobilizing agents for periods yielding maximal tyrosine phosphorylation response: angiotensin II (A II; $1 \mu \mathrm{M}, 45 \mathrm{~s}$ ), thapsigargin (THAPS; 2 $\mu \mathrm{M}, 5 \mathrm{~min}$ ), ionomycin (IONO; $10 \mu \mathrm{M}, 1 \mathrm{~min})$, and A23187 $(10 \mu \mathrm{M}$ $5 \mathrm{~min})$ in the absence of $o$-vanadate or ionomycin $(10 \mu \mathrm{M}, 2.5 \mathrm{~min})$ or A23187 $(10 \mu \mathrm{M}, 5 \mathrm{~min})$ in the presence of $200 \mu \mathrm{M} o$-vanadate (15-min preincubation). Results shown are representative of three separate experiments.

is postulated to allow the release of $\mathrm{Ca}^{2+}$ from inositol trisphosphate-sensitive stores (65), produced a pattern of protein-tyrosine phosphorylation strongly resembling that seen in response to angiotensin II, as did the calcium ionophores A23187 and ionomycin. The phosphatase inhibitor $o$-vanadate alone $(200 \mu \mathrm{M}, 15 \mathrm{~min})$ produced small increases in tyrosine phosphorylation. $o$-Vanadate enhanced the response to either ionophore, but its effect on A23187 action was more pronounced, allowing the detection of several species in the $50-$ to $90-\mathrm{kDa}$ range not seen in angiotensin II-treated cells (Fig. 3).

To corroborate the results obtained by anti-P-Tyr immunoblotting, ${ }^{32} \mathbf{P}_{\mathrm{i}}$-labeled WB cells were treated with EGF, angiotensin II, or A23187 plus $o$-vanadate. $\left[{ }^{32} \mathrm{P}\right] \mathrm{Tyr}$-containing proteins were recovered by anti-P-Tyr immunoprecipitation, separated by SDS-PAGE, and transferred to Immobilon membranes. Autoradiography revealed patterns of increased phosphorylation similar to those observed by using anti-P-Tyr immunoblotting. These experiments (Fig. 4) confirmed that proteins in the molecular weight ranges detected by immunoblotting (Fig. 1 to 3 ) did contain elevated $\mathrm{P}$-Tyr content as a consequence of treatment with angiotensin II or A23187.

To test the potential involvement of $\mathrm{PKC}$ in angiotensin II-dependent tyrosine phosphorylation, WB cells were treated with PMA, an exogenous activator of PKC. Acute PMA treatment $(300 \mathrm{nM}, 0.25$ to $10 \mathrm{~min})$ produced small increases in P-Tyr-p120/125 and P-Tyr-p75/78 in two of four replicate experiments and no effects in the remaining experiments (not shown).

Angiotensin II-stimulated increases in tyrosine phosphorylation are coupled to calcium mobilization. To examine the temporal relationship between $\mathrm{Ca}^{2+}$ mobilization and tyrosine phosphorylation, cytosolic $\mathrm{Ca}^{2+}$ levels were monitored in cells loaded with the fluorescent indicator fura- 2 . The $\mathrm{Ca}^{2+}$ responses to angiotensin II or thapsigargin were

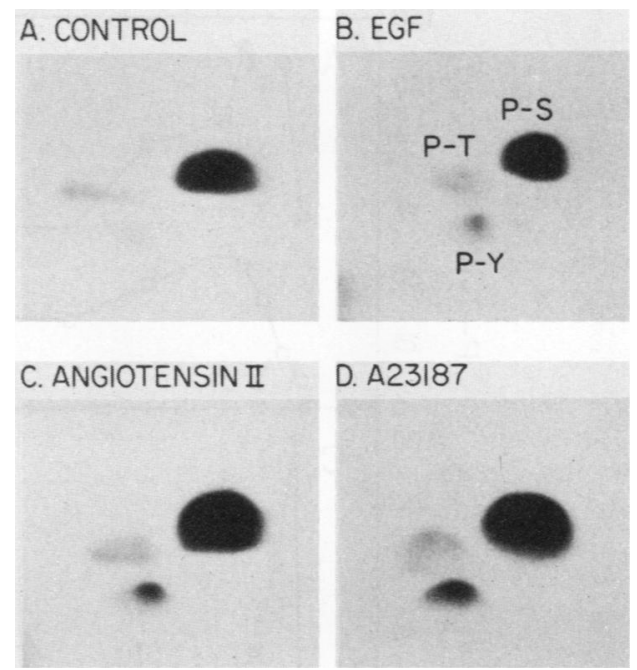

FIG. 4. Phosphoamino acid analysis of ${ }^{32} \mathrm{P}-\mathrm{p} 75 / 78$. WB cells were prelabeled with ${ }^{32} \mathrm{P}_{\mathrm{i}}$ for $2 \mathrm{~h}$ before treatment with vehicle (A), $300 \mathrm{ng}$ of EGF per $\mathrm{ml}(\mathrm{B}), 1 \mu \mathrm{M}$ angiotensin II (C), or $10 \mu \mathrm{M}$ A23187 plus $200 \mu \mathrm{M} o$-vanadate (D). ${ }^{32} \mathrm{P}$-proteins were recovered by monoclonal anti-P-Tyr immunoprecipitation and subjected to SDS-PAGE and phosphoamino acid analysis as described in Materials and Methods. Results (representative of three similar experiments) show two-dimensional electrophoretic separations of phosphoamino acids derived from the $\mathrm{p} 75 / 78$ species. In the same experiment, the p120/125 region from angiotensin II- and A23187-treated cells likewise showed increased $\left[{ }^{32} \mathrm{P}\right] \mathrm{T} y \mathrm{r}$ content. The $\left[{ }^{32} \mathrm{P}\right] \mathrm{Tyr}$ spots from control, EGF-, angiotensin II-, and A23187-treated samples shown contained $17,25,57$, and $99 \mathrm{cpm}$ above blank, respectively, determined by liquid scintillation counting.

coincident with the measurable changes in tyrosine phosphorylation (Fig. 5). Angiotensin II stimulated more rapid $(\leq 5-\mathrm{s})$ increases in $\left[\mathrm{Ca}^{2+}\right]$, accompanied by transient increases in P-Tyr-protein levels. The $\mathrm{Ca}^{2+}$ increase in response to thapsigargin was maximal after 2 to $3 \mathrm{~min}$ and persisted, along with elevated P-Tyr-proteins, for $\geq 5 \mathrm{~min}$. Thapsigargin stimulates a similarly persistent elevation of $\left[\mathrm{Ca}^{2+}\right]$ in hepatocytes (67).

If the increases in tyrosine phosphorylation in response to angiotensin II, ionophores, or thapsigargin are secondary to $\mathrm{Ca}^{2+}$ mobilization, blockade of the $\mathrm{Ca}^{2+}$ increase provoked by these agents should inhibit their capacity to increase tyrosine phosphorylation. Treatment of WB cells with angiotensin II in the presence of $5 \mathrm{mM}$ EGTA had minimal effects on the response to angiotensin II (not shown), consistent with the preferred utilization of $\mathrm{Ca}^{2+}$ from intracellular rather than extracellular sources. To block increases in cytosolic $\mathrm{Ca}^{2+}$ irrespective of its origin, WB cells were incubated with the membrane-permeant compound BAPTAAM, which is hydrolyzed to the active chelator BAPTA upon entry into cells $(72,73)$. The concentrations of BAPTA-AM used were sufficient to inhibit EGF- or angiotensin II-induced increases in intracellular $\left[\mathrm{Ca}^{2+}\right]$ in hepatocytes, as measured by digital video fluorescence microscopy (B. Herman, unpublished data). BAPTA inhibited the increases in all angiotensin II- and thapsigargin-stimulated P-Tyr-proteins (p66, p75, and p125; Fig. 6); on longer exposure of autoradiographs from $7 \%$ polyacrylamide gels, blockade of the minor angiotensin II-sensitive species, P-Tyr-p93 and -p57, also was noted in BAPTA-loaded cells (not shown). In contrast, BAPTA loading did not inhibit EGF receptor autophosphorylation (p170), the increases in 


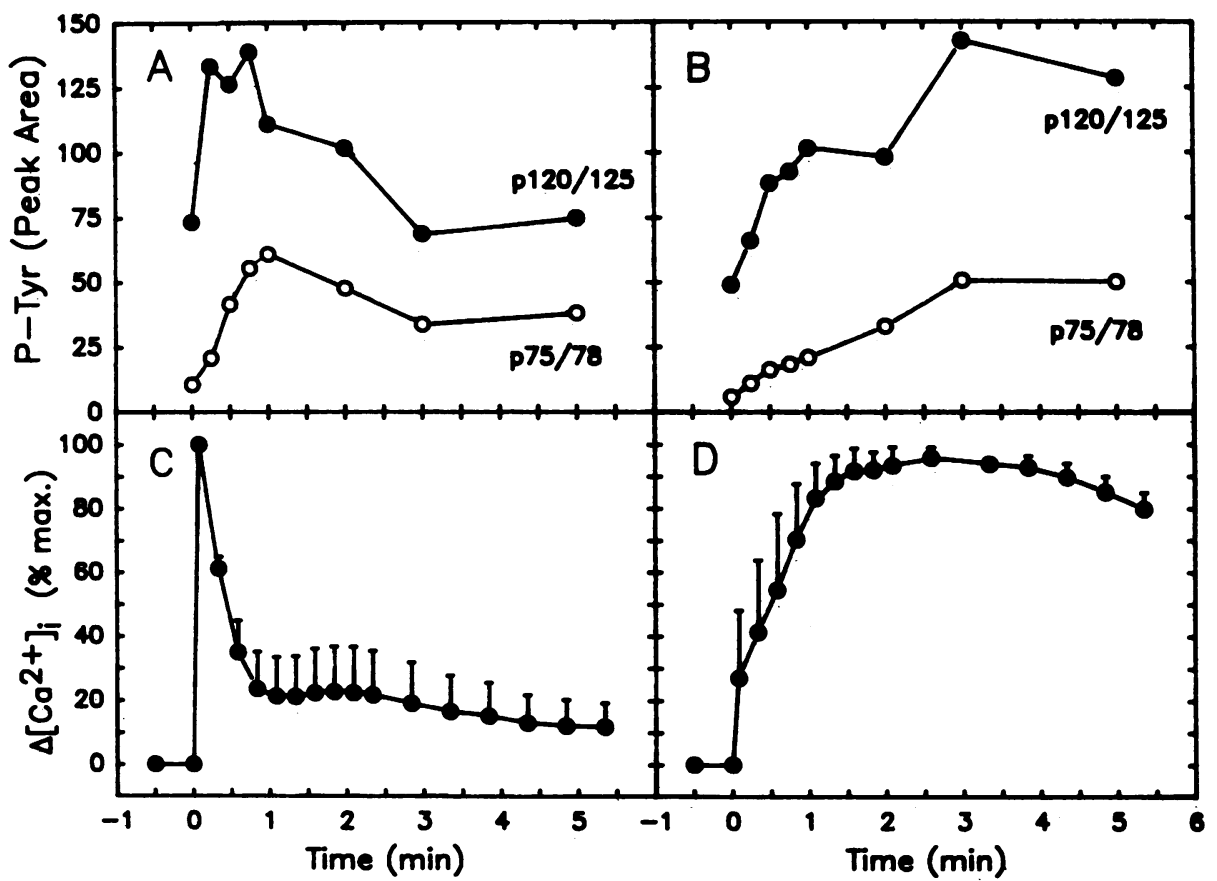

FIG. 5. Time courses of angiotensin II- or thapsigargin-stimulated tyrosine phosphorylation and $\mathrm{Ca}^{2+}$ mobilization. (A and B) WB cells in 35-mm-diameter culture dishes were treated with $1 \mu \mathrm{M}$ angiotensin II (A) or $2 \mu \mathrm{M}$ thapsigargin (B) for the times indicated, and tyrosine phosphorylation was assessed by immunoblotting. Relative intensities of autoradiographic bands in the p75/78 and p120/125 regions were estimated by scanning densitometry. Data shown (representative of three experiments) are expressed as densitometric peak area (arbitrary units). (C and D) WB cells grown on 22-by-22-mm cover slips were loaded with fura-2 and monitored for free intracellular [Ca $\left.{ }^{2+}\right]$ by digital video fluorescence microscopy as described in Materials and Methods. Each time point is the mean free $\left[\mathrm{Ca}^{2+}\right]$ across a microscopic field containing five to six cells selected at random. Results are expressed as the mean \pm standard error (of three separate experiments) of percent maximal change in intracellular $\left[\mathrm{Ca}^{2+}\right]\left(\left[\mathrm{Ca}^{2+}\right]_{\mathrm{i}}\right)$ observed in response to $1 \mu \mathrm{M}$ angiotensin II (C) or $2 \mu \mathrm{M}$ thapsigargin (D). Preaddition and peak intracellular $\left[\mathrm{Ca}^{2+}\right]$ values for angiotensin II-treated cells were $275 \pm 36$ and $1,002 \pm 65 \mathrm{nM}$, respectively; corresponding values for thapsigargin-treated cells were $320 \pm 35$ and $926 \pm 185 \mathrm{nM}$, respectively.

P-Tyr-p115, -p75, and -p59 seen in response to EGF, or the increases in P-Tyr-p100 and -p40 noted in longer exposures (not shown). However, BAPTA was noted to inhibit the EGF-stimulated increases in P-Tyr-p120 and -p66 (Fig. 6). These results were obtained reproducibly in four separate experiments. The persistence of EGF receptor phosphorylation in the presence of BAPTA is consistent with the reported insensitivity of the EGF receptor kinase to $\mathrm{Ca}^{2+}$

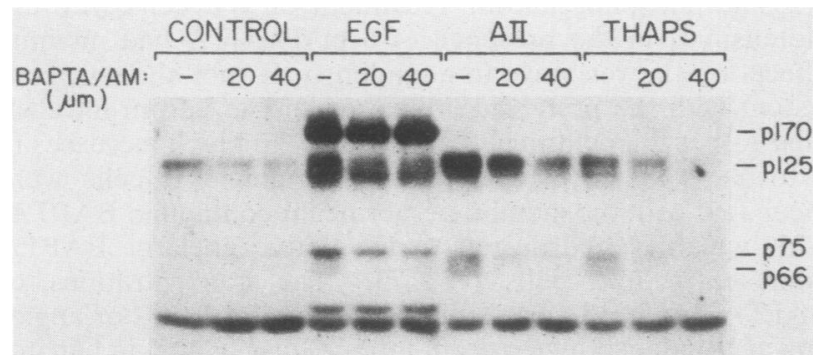

FIG. 6. Effects of BAPTA on tyrosine phosphorylation in WB cells. WB cells were loaded with BAPTA by preincubation with the indicated concentrations of BAPTA-AM for $15 \mathrm{~min}$ at $37^{\circ} \mathrm{C}$. Cells were treated with EGF $(300 \mathrm{ng} / \mathrm{ml}, 1 \mathrm{~min})$, angiotensin II (AII; $1 \mu \mathrm{M}$, $45 \mathrm{~s}$ ), or thapsigargin (THAPS; $2 \mu \mathrm{M}, 5 \mathrm{~min}$ ), conditions that elicit maximal tyrosine phosphorylation responses. Immunoblotting was performed after electrophoresis on $10 \%$ polyacrylamide gels, on which the diffuse angiotensin II-sensitive species of p120/125 and p75/78 kDa migrated as single bands. Results shown are representative of four separate experiments.
(21) and serves as a control for nonspecific or toxic effects of BAPTA on WB cells. Additional experiments using BAPTAloaded cells confirmed that the marked potentiation of A23187 action by $o$-vanadate was indeed $\mathrm{Ca}^{2+}$ dependent (not shown).

As an additional test of the involvement of PKC (a major intracellular target of mobilized $\mathrm{Ca}^{2+}$ ) in angiotensin IIstimulated tyrosine phosphorylation, WB cells were treated with a high concentration of PMA for $18 \mathrm{~h}$ before challenge with angiotensin II. This pretreatment protocol reduces WB cell PKC activity to $\leq 4 \%$ of control levels (38) and eliminates the ability of phorbol esters to inhibit EGF- or angiotensin II-stimulated PtdIns hydrolysis (38) and EGF-stimulated tyrosine phosphorylation of PLC $\gamma$ (Huckle et al., in press). In PKC-depleted cells, there was no reduction in the ability of angiotensin II to increase tyrosine phosphorylation compared with results for control cells (Fig. 7). In fact, PKC depletion prolonged the angiotensin II-stimulated elevation of tyrosine phosphorylation, although increases in magnitude were not apparent.

\section{DISCUSSION}

The peptide hormone angiotensin II exerts effects on a variety of tissues, including vascular smooth muscle (vasoconstriction), the adrenal gland (synthesis and release of aldosterone and catecholamines), and the liver (glycogenolysis). Activation of angiotensin II receptors typically is associated with the generation of $\mathrm{Ca}^{2+}$-mobilizing inositol phosphates and PKC-activating diacylglycerols from PtdIns 

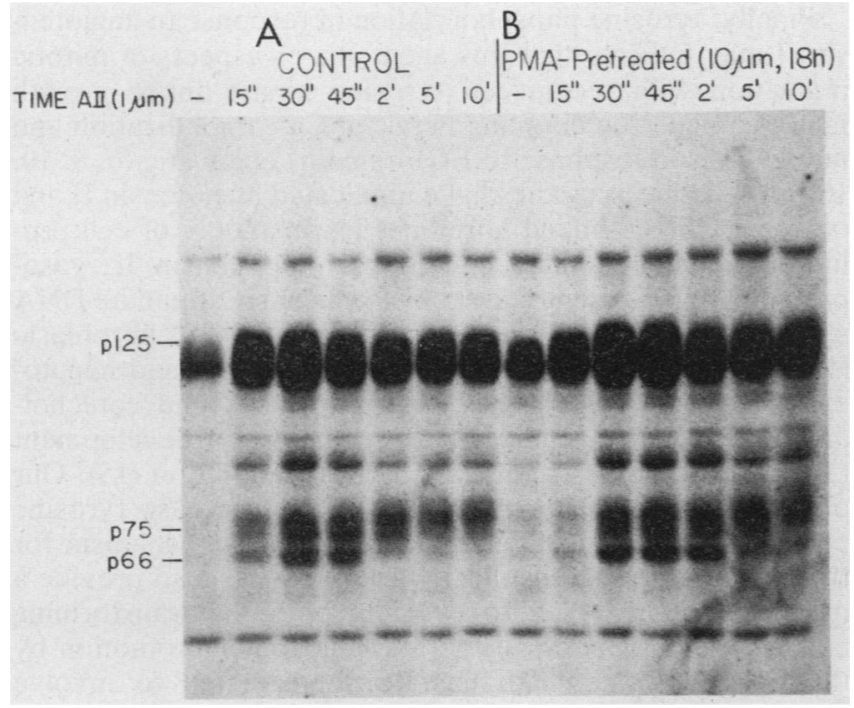

FIG. 7. Effect of PKC depletion on angiotensin II-stimulated tyrosine phosphorylation. WB cell cultures were treated with $0.1 \%$ dimethyl sulfoxide (A) or $10 \mu \mathrm{M}$ PMA (B) for $18 \mathrm{~h}$ before addition of angiotensin II (AII) for the times indicated (", seconds; ', minutes). Tyrosine phosphorylation then was assessed by anti-P-Tyr immunoblotting. Results shown are representative of three separate experiments.

(reviewed in reference 33). Cellular responses to these intracellular messengers are thought to be mediated in part by the targets of PKC and $\mathrm{Ca}^{2+} /$ calmodulin-dependent protein kinases (19). The results of this study on WB cells suggest that angiotensin II, as well as $\left[\mathrm{Arg}^{8}\right]$ vasopressin and epinephrine, also may influence cell function through tyrosine phosphorylation. These agents increased the tyrosine phosphorylation of several proteins, as detected by immunoblotting with either affinity-purified polyclonal or monoclonal anti-P-Tyr antibodies and confirmed by $\left[{ }^{32} \mathrm{P}\right]$ phosphoamino acid analysis.

Previous studies in WB cells (49) revealed two classes of proteins whose tyrosine phosphorylation is increased by EGF: (i) those phosphorylated within 5 to $15 \mathrm{~s}$ of EGF addition (EGF receptor, p115, p100, p75, p66, p57, and p52) and (ii) those not detected until 45 to $90 \mathrm{~s}$ after EGF addition (p120, p78, and p38). The first group of proteins also was phosphorylated, albeit with slower kinetics, when EGF was added to cells at $4^{\circ} \mathrm{C}$ (a condition that blocks EGF-stimulated PtdIns hydrolysis and receptor endocytosis), whereas the latter group was not detected at $4^{\circ} \mathrm{C}$. We postulated that the temperature-sensitive phosphorylations reflected a requirement for dynamic intracellular events, such as EGF receptor internalization or phosphorylation by another tyrosine kinase activated secondarily by EGF. Indeed, these results indicate that WB cells contain an angiotensin II-activated pathway that can increase protein-tyrosine phosphorylation in a manner apparently independent of the EGF receptor kinase. Molecular weight profiles and preliminary subcellular fractionation studies suggest that angiotensin II and EGF may increase the tyrosine phosphorylation of overlapping sets of proteins, but more definitive evidence that EGF and angiotensin II act on identical proteins is needed.

The receptor for angiotensin II is not well characterized biochemically, although Jackson et al. have reported that the mas oncogene may encode an angiotensin receptor capable of coupling to $\mathrm{Ca}^{2+}$ mobilization (42). The predicted amino acid sequence of neither the mas product nor the $\alpha_{1^{-}}$ adrenergic receptor cDNA (13) indicates the presence of a tyrosine kinase domain. Instead, available evidence suggests that receptors of this type activate PtdIns hydrolysis through a receptor-associated GTP-binding protein $(20,33,38 a)$. Consistent with this proposed mechanism, increases in tyrosine phosphorylation stimulated by angiotensin II, [ $\mathrm{Arg}^{8}$ ] vasopressin, or epinephrine were mimicked by NaF (Huckle et al., unpublished results), a G-protein activator which stimulates inositol trisphosphate production in WB cells (38). Furthermore, similar patterns of tyrosine phosphorylation also were provoked by the calcium-mobilizing agent thapsigargin and the $\mathrm{Ca}^{2+}$ ionophores A23187 and ionomycin. All angiotensin II-stimulated increases in P-Tyr-proteins were blocked by loading cells with the $\mathrm{Ca}^{2+}$ chelator BAPTA but not by depleting cellular PKC activity. The effects of angiotensin II on tyrosine phosphorylation thus appear to be secondary to, and dependent on, $\mathrm{Ca}^{2+}$ mobilization but not PKC activation. The inhibition of EGFstimulated tyrosine phosphorylation of p120 and p66 by BAPTA suggests that these events likewise may be $\mathrm{Ca}^{2+}$ dependent. The failure of BAPTA to inhibit EGF-stimulated increases in P-Tyr-p75 suggests that this protein is not identical to the p75 affected by angiotensin II or that distinct kinases or phosphorylation sites are utilized in response to EGF and angiotensin II.

Recently, several agents not usually associated with tyrosine kinase activity have been found to increase levels of tyrosine phosphorylation. These include thrombin $(22,30$, 46), collagen (50), and vasopressin (32) in platelets, fMetLeuPhe in neutrophils (39), muscarinic agonists in hippocampal slices (64), and phytohemagglutinin in Jurkat $T$ cells (69). Disparate findings have been reported regarding the signaling pathways involved in this atypical tyrosine phosphorylation. Several studies using phorbol esters $(22,23,64)$ have indicated a possible role for PKC in tyrosine phosphorylation. In permeabilized neutrophils, GTP $\gamma \mathrm{S}$-stimulated increase in P-Tyr-protein levels was not mimicked by exogenous diacylglycerols (51), but the role of $\mathrm{Ca}^{2+}$ was not examined. Other investigators have reported that immunoglobulin E-stimulated tyrosine phosphorylation in RBL-2H3 basophils proceeds in a $\mathrm{Ca}^{2+}$-independent manner (3). In contrast, our studies in WB cells establish a link between hormone-induced $\mathrm{Ca}^{2+}$ mobilization and increased levels of tyrosine phosphorylation.

While the mechanism by which $\mathrm{Ca}^{2+}$ increases tyrosine phosphorylation in WB cells has not been determined, the most straightforward possibility is direct activation of a tyrosine kinase by $\mathrm{Ca}^{2+}$ or by a $\mathrm{Ca}^{2+}$-binding regulatory protein. This mechanism would be analogous to regulation of serine/threonine protein kinases by $\mathrm{Ca}^{2+} /$ calmodulin (19). A related possibility is that $\mathrm{Ca}^{2+}$-dependent enzymes activate a tyrosine kinase, perhaps by phosphorylation (54) or proteolysis. Alternatively, $\mathrm{Ca}^{2+}$ might modulate tyrosine phosphorylation by promoting substrate interaction with a tyrosine kinase. Precedent for such a model exists in that lipocortin I (p35; calpactin II) requires $\mathrm{Ca}^{2+}$ in order to bind to phospholipid membranes and to serve as a substrate for the EGF receptor tyrosine kinase $(17,21)$. Similarly, phosphorylation of calpactin I (p36; lipocortin II) by the pp60 6 -src tyrosine kinase is markedly enhanced in the presence of $\mathrm{Ca}^{2+}$ and phospholipid $(14,28)$.

A third possible mechanism by which $\mathrm{Ca}^{2+}$ might modulate tyrosine phosphorylation is inhibition of tyrosine phosphatase activity. Recent studies of protein-tyrosine phosphatases have demonstrated that these enzymes are greater 
in number and likely are subject to closer regulation than once was appreciated $(40,70)$. In our studies, treatment with $o$-vanadate alone was accompanied by detectable increases in the tyrosine phosphorylation of p75/78 and p120/125 (Fig. $3)$. Thus, p75/78 and p120/125 may continually undergo phosphorylation and dephosphorylation such that phosphatase inhibition alone might permit some accumulation of their phosphorylated forms. However, angiotensin II, thapsigargin, and $\mathrm{Ca}^{2+}$ ionophores clearly have effects on tyrosine phosphorylation greater in magnitude than those induced by $o$-vanadate alone, and the response to angiotensin II or ionophores plus $o$-vanadate is (at least) additive. Moreover, the more rapid dephosphorylation of P-Tyr-p66 relative to other angiotensin II-sensitive substrates, even in the presence of $o$-vanadate (not shown), suggests that inhibition of a single phosphatase cannot account wholly for the effects of angiotensin II on tyrosine phosphorylation.

$o$-Vanadate has been reported to have other cellular effects, including activation of the insulin receptor kinase (66), a G-protein coupled to PLC (53), and $\mathrm{Ca}^{2+}$ influx (48), which could partially mimic the effects of angiotensin II. The potentially pleiotropic effects of $o$-vanadate may contribute to the marked synergism between A23187 and $o$-vanadate (Fig. 3). Alternatively, the synergism may arise from enhanced phosphatase inhibition by supraphysiological intracellular $\left[\mathrm{Ca}^{2+}\right]$ induced by $\mathrm{A} 23187$ or from undetermined actions of $o$-vanadate metabolites (44). Regardless of its molecular mechanism, the marked interaction between A23187 and $o$-vanadate indicates that WB cells contain high levels of latent tyrosine-phosphorylating activity.

Although tyrosine phosphorylation has been studied principally in the context of cell proliferation, evidence from several systems suggests that this protein modification also may regulate acute metabolic responses to stimuli. A leading example is the insulin receptor tyrosine kinase (75), which appears to be essential for insulin-stimulated responses such as glucose uptake and glycogen synthesis (11). In other systems, tyrosine phosphorylation has been implicated in secretion from adrenal chromaffin cells (52), platelets (47), and basophils (3) and in superoxide production in neutrophils (31). The very presence of tyrosine kinases and phosphatases in cells which are characteristically nonproliferative (e.g., neutrophils; 5) or terminally differentiated (e.g., neural retina; 62) implies that tyrosine phosphorylation may participate in a broad spectrum of cellular activities.

Alternatively, angiotensin II-stimulated tyrosine phosphorylation, in addition to serine/threonine phosphorylation, may be involved in longer-term anabolic responses. Angiotensin II increases levels of mRNAs for the EGF receptor in WB cells (18), angiotensinogen in hepatocytes $(2,45)$, and catecholamine-synthesizing enzymes in adrenal medullary cells (63). Both angiotensin II (26) and [ $\mathrm{Arg}^{8}$ ] vasopressin (25) stimulate hypertrophy of vascular smooth muscle cells. Angiotensin II activates ribosomal $\mathrm{S}_{6}$ kinase (60) and protein synthesis in smooth muscle cells in a $\mathrm{Ca}^{2+}$-dependent fashion (4). These last findings are especially notable in light of the recent report that MAP-2 kinase requires phosphorylation on both tyrosine and threonine residues in order to activate $S_{6}$ kinase (1). Thus, MAP-2 kinase (pp42), which can be phosphorylated on tyrosine in response to EGF, platelet-derived growth factor, phorbol esters, or thrombin (56), becomes another candidate for angiotensin II-stimulated tyrosine phosphorylation. Although we have not detected a P-Tyr-p42 in lysates of angiotensin II-treated WB cells, this protein, like P-Tyr-PLC $\gamma$ (Huckle et al., in press), might escape detection without enrichment from lysates.
Finally, tyrosine phosphorylation in response to angiotensin II may indicate that this agent shares aspects of mitotic regulation with recognized tyrosine kinase-linked growth factors. While the coupling between $\mathrm{Ca}^{2+}$ mobilization and mitogenesis in response to EGF remains enigmatic $(6,8,10$, $16,74)$, numerous studies have implicated angiotensin II and other $\mathrm{Ca}^{2+} / \mathrm{PKC}$-linked hormones as regulators of cell proliferation under defined conditions. Angiotensin II, vasopressin, and $\alpha_{1}$-adrenergic agonists variously stimulate DNA synthesis in adrenal cortex $(27,55)$, mouse $3 \mathrm{~T} 3$ fibroblasts $(57,59,61)$, vascular smooth muscle cells (7), and hepatocytes (15). Accordingly, peptide hormones and catecholamines have been implicated as regulators of development $(37,79)$, angiogenesis (24), and liver regeneration (15). Our observation that $\mathrm{Ca}^{2+}$-mobilizing agents increase tyrosine phosphorylation indicates another potential mechanism for their growth-promoting effects. These results also provide a new context in which to evaluate both the transforming activity of the mas oncogene (42) and tumor promotion by thapsigargin (35), which has been postulated to involve chronic elevation of intracellular $\left[\mathrm{Ca}^{2+}\right](68)$.

\section{ACKNOWLEDGMENTS}

This work was supported by Public Health Service grants DK31683 to H.S.E. and AG07218 and CA16086 to B.H. and National Research Service award F32 DK08378 to W.R.H. from the National Institutes of Health and by the Gustavus and Louise Pfeiffer Foundation (B.H.).

We thank Alice Berry for preparation of cell cultures, Ammasi Perisammy for performing the video fluorescence $\mathrm{Ca}^{2+}$ analyses, David Lee, Craig McArdle, and Bryan McCune for helpful discussions, and Mary Davis and Jane Radford for preparing the manuscript.

\section{LITERATURE CITED}

1. Anderson, N. G., J. L. Maller, N. K. Tonks, and T. W. Sturgill. 1990. Requirement for integration of signals from two distinct phosphorylation pathways for activation of MAP kinase. Nature (London) 343:651-653.

2. Ben-Ari, E. T., and J. C. Garrison. 1988. Regulation of angiotensinogen mRNA accumulation in rat hepatocytes. Am. J. Physiol. 255:E70-E79.

3. Benhamou, M., J. S. Gutkind, K. C. Robbins, and R. P. Siraganian. 1990. Tyrosine phosphorylation coupled to IgE receptor-mediated signal transduction and histamine release. Proc. Natl. Acad. Sci. USA 87:5327-5330.

4. Berk, B. C., V. Vekshtein, H. M. Gordon, and T. Tsuda. 1989. Angiotensin II-stimulated protein synthesis in cultured vascular smooth muscle cells. Hypertension 13:305-314.

5. Berkow, R. L., R. W. Dodson, and A. S. Kraft. 1989. Human neutrophils contain distinct cytosolic and particulate tyrosine kinase activities: possible role in neutrophil activation. Biochim. Biophys. Acta 997:292-301.

6. Besterman, J. M., S. P. Watson, and P. Cuatrecasas. 1986. Lack of association of epidermal growth factor-, insulin-, and seruminduced mitogenesis with stimulation of phosphoinositide degradation in BALB/c 3T3 fibroblasts. J. Biol. Chem. 261:723-727.

7. Bobik, A., S. Grinpukel, P. J. Little, A. Grooms, and G. Jackman. 1990. Angiotensin II and noradrenaline increase PDGF-BB receptors and potentiate PDGF-BB stimulated DNA synthesis in vascular smooth muscle. Biochem. Biophys. Res. Commun. 166:580-588.

8. Bravo, R., J. Burckhardt, T. Curran, and R. Muller. 1985. Stimulation and inhibition of growth by EGF in different A431 cell clones is accompanied by the rapid induction of c-fos and c-myc proto-oncogenes. EMBO J. 4:1193-1197.

9. Carpenter, G. 1987. Epidermal growth factor. Annu. Rev. Biochem. 56:881-914.

10. Chen, W. S., C. S. Lazar, M. Poenie, R. Y. Tsien, G. N. Gill, and M. G. Rosenfeld. 1987. Requirement for intrinsic protein ty- 
rosine kinase in the immediate and late actions of the EGF receptor. Nature (London) 328:820-823.

11. Chou, C. K., T. J. Dull, D. S. Russell, R. Gherzi, D. Lebwohl, A. Ullrich, and O. M. Rosen. 1987. Human insulin receptors mutated at the ATP-binding site lack protein kinase activity and fail to mediate postreceptor effects of insulin. J. Biol. Chem. 262:1842-1847.

12. Cooper, J. A., B. M. Sefton, and T. Hunter. 1983. Detection and quantification of phosphotyrosine in proteins. Methods Enzymol. 99:387-402.

13. Cotecchia, S., D. A. Schwinn, R. R. Randall, R. J. Lefkowitz, M. G. Caron, and B. K. Kobilka. 1988. Molecular cloning and expression of the cDNA for the hamster $\alpha_{1}$-adrenergic receptor. Proc. Natl. Acad. Sci. USA 85:7159-7163.

14. Courtneidge, S., R. Ralston, K. Alitalo, and J. M. Bishop. 1983. Subcellular location of an abundant substrate (p36) for tyrosinespecific protein kinases. Mol. Cell. Biol. 3:340-350.

15. Cruise, J. L., K. A. Houck, and G. K. Michalopoulos. 1985. Induction of DNA synthesis in cultured rat hepatocytes through stimulation of $\alpha_{1}$ adrenoceptor by norepinephrine. Science 227:749-751.

16. Cutry, A. F., A. J. Kinniburgh, M. J. Krabak, S.-W. Hui, and C. E. Wenner. 1989. Induction of c-fos and c-myc protooncogene expression by epidermal growth factor and transforming growth factor $\alpha$ is calcium-independent. J. Biol. Chem. 264:19700-19705.

17. De, B. K., K. S. Misono, T. J. Lukas, B. Mroczkowski, and S. Cohen. 1986. A calcium-dependent 35-kilodalton substrate for epidermal growth factor receptor/kinase isolated from normal tissue. J. Biol. Chem. 261:13784-13792.

18. Earp, H. S., J. R. Hepler, L. A. Petch, A. Miller, A. R. Berry, J. Harris, V. W. Raymond, B. K. McCune, L. W. Lee, J. W. Grisham, and T. K. Harden. 1988. Epidermal growth factor (EGF) and hormones stimulate phosphoinositide hydrolysis and increase EGF receptor protein synthesis and mRNA levels in rat liver epithelial cells. J. Biol. Chem. 263:13868-13874.

19. Edelman, A. M., D. K. Blumenthal, and E. G. Krebs. 1987. Protein serine/threonine kinases. Annu. Rev. Biochem. 56:567613.

20. Fain, J. N., M. A. Wallace, and R. J. H. Wojcikiewicz. 1988. Evidence for involvement of guanine nucleotide-binding regulatory proteins in the activation of phospholipases by hormones. FASEB J. 2:2569-2574.

21. Fava, R. A., and S. Cohen. 1984. Isolation of a calciumdependent 35-kilodalton substrate for the epidermal growth factor receptor/kinase from A-431 cells. J. Biol. Chem. 259: 2636-2645.

22. Ferrell, J. E., and G. S. Martin. 1988. Platelet tyrosine-specific protein phosphorylation is regulated by thrombin. Mol. Cell. Biol. 8:3603-3610.

23. Ferris, D. K., J. Willette-Brown, T. Martensen, and W. L. Farrar. 1989. Interleukin 3 and phorbol ester stimulate tyrosine phosphorylation of overlapping substrate proteins. FEBS Lett. 246:153-158.

24. Frohlich, E. D., T. Iwata, and O. Sasaki. 1989. Clinical and physiologic significance of local tissue renin-angiotensin systems. Am. J. Med. 87(Suppl. 6B):19S-23S.

25. Geisterfer, A. A. T., and G. K. Owens. 1989. Arginine vasopressin-induced hypertrophy of cultured aortic smooth muscle cells. Hypertension 14:413-420.

26. Geisterfer, A. A. T., M. J. Peach, and G. K. Owens. 1988. Angiotensin II induces hypertrophy, not hyperplasia, of cultured rat aortic smooth muscle cells. Circ. Res. 62:749-756.

27. Gill, G. N., C. R. III, and M. H. Simonian. 1977. Angiotensin stimulation of bovine adrenocortical cell growth. Proc. Natl. Acad. Sci. USA 74:5569-5573.

28. Glenney, J. 1986. Two related but distinct forms of the $M_{r} 36,000$ tyrosine kinase substrate (calpactin) that interacts with phospholipid and actin in a $\mathrm{Ca}^{2+}$-dependent manner. Proc. Natl. Acad. Sci. USA 83:4258-4262.

29. Glenney, J. R., L. Zokas, and M. P. Kamps. 1988. Monoclonal antibodies to phosphotyrosine. J. Immunol. Methods 109:277285 .
30. Golden, A., and J. S. Brugge. 1989. Thrombin treatment induces rapid changes in tyrosine phosphorylation in platelets. Proc. Natl. Acad. Sci. USA 86:901-905.

31. Gomez-Cambronero, J., C.-K. Huang, V. A. Bonak, E. Wang, J. E. Casnellie, T. Shiraishi, and R. I. Sha'afi. 1989. Tyrosine phosphorylation in human neutrophil. Biochem. Biophys. Res. Commun. 162:1478-1485.

32. Granot, Y., V. Van Putten, and R. W. Schrier. 1990. Vasopressin dependent tyrosine phosphorylation of a $38 \mathrm{kDa}$ protein in human platelets. Biochem. Biophys. Res. Commun. 168:566573.

33. Griendling, K. K., B. C. Berk, L. Socorro, T. Tsuda, P. Delafontaine, and R. W. Alexander. 1988. Secondary signalling mechanisms in angiotensin II-stimulated vascular smooth muscle cells. Clin. Exp. Pharmacol. Physiol. 15:105-112.

34. Grynkiewicz, G., M. Poenie, and R. Y. Tsien. 1985. A new generation of $\mathrm{Ca}^{2+}$ indicators with greatly improved fluorescence properties. J. Biol. Chem. 260:3440-3450.

35. Hakii, H., H. Fujiki, M. Suganuma, M. Nakayasu, T. Tahira, T. Sugimura, P. J. Scheuer, and S. B. Christensen. 1986. Thapsigargin, a histamine secretagogue, is a non-12-0-tetradecanoylphorbol-13-acetate (TPA) type tumor promoter in twostage mouse skin carcinogenesis. J. Cancer Res. Clin. Oncol. 111:177-181.

36. Hanks, S. K., A. M. Quinn, and T. Hunter. 1988. The protein kinase family: conserved features and deduced phylogeny of the catalytic domains. Science 241:42-52.

37. Hanley, M. R. 1985. Neuropeptides as mitogens. Nature (London) 315:14-15

38. Hepler, J. R., H. S. Earp, and T. K. Harden. 1988. Long-term phorbol ester treatment down-regulates protein kinase $C$ and sensitizes the phosphoinositide signaling pathway to hormone and growth factor stimulation. J. Biol. Chem. 263:7610-7619.

38a.Hepler, J. R., R. A. Jefís, W. R. Huckle, H. E. Outlaw, S. G. Rhee, H. S. Earp, and T. K. Harden. 1990. Evidence that the epidermal growth factor receptor and non-tyrosine kinase hormone receptors stimulate phosphoinositide hydrolysis by independent pathways. Biochem J. 270:337-344.

39. Huang, C.-K., G. R. Laramee, and J. E. Casnellie. 1988. Chemotactic factor induced tyrosine phosphorylation of membrane associated proteins in rabbit peritoneal neutrophils. Biochem. Biophys. Res. Commun. 151:794-801.

40. Hunter, T. 1989. Protein-tyrosine phosphatases: the other side of the coin. Cell 58:1013-1016.

41. Hunter, T., and J. A. Cooper. 1985. Protein-tyrosine kinases. Annu. Rev. Biochem. 54:897-930.

42. Jackson, T. R., L. A. C. Blair, J. Marshall, M. Goedert, and M. R. Hanley. 1988. The mas oncogene encodes an angiotensin receptor. Nature (London) 335:437-440.

43. Kamps, M. P., and B. M. Sefton. 1989. Acid and base hydrolysis of phosphoproteins bound to Immobilon facilitates analysis of phosphoamino acids in gel-fractionated proteins. Anal. Biochem. 176:22-27.

44. Klarlund, J. K. 1985. Transformation of cells by an inhibitor of phosphatases acting on phosphotyrosine in proteins. Cell 41: 707-717.

45. Klett, C., W. Hellmann, F. Suzuki, S. Nakanishi, H. Ohkubo, D. Ganten, and E. Hackenthal. 1988. Induction of angiotensinogen mRNA in hepatocytes by angiotensin II and glucocorticoids. Clin. Exp. Hypertens. A10:1009-1022.

46. Kohno, M., and J. Pouyssegur. 1986. $\alpha$-Thrombin-induced tyrosine phosphorylation of 43000 - and $41000-M_{r}$ proteins is independent of cytoplasmic alkalinization in quiescent fibroblasts. Biochem. J. 238:451-457.

47. Lerea, K. M., N. K. Tonks, E. G. Krebs, E. H. Fischer, and J. A. Glomset. 1989. Vanadate and molybdate increase tyrosine phosphorylation in a 50-kilodalton protein and stimulate secretion in electropermeabilized platelets. Biochemistry 28:9286-9292.

48. Macara, I. G. 1986. Activation of ${ }^{45} \mathrm{Ca}^{2+}$ influx and ${ }^{22} \mathrm{Na}^{+} / \mathrm{H}^{+}$ exchange by epidermal growth factor and vanadate in A431 cells is independent of phosphatidylinositol turnover and is inhibited by phorbol ester and diacylglycerol. J. Biol. Chem. 261:93219237. 
49. McCune, B. K., and H. S. Earp. 1989. The epidermal growth factor receptor tyrosine kinase in liver epithelial cells. J. Biol. Chem. 264:15501-15507.

50. Nakamura, S., and H. Yamamura. 1989. Thrombin and collagen induce rapid phosphorylation of a common set of cellular proteins on tyrosine in human platelets. J. Biol. Chem. 264: 7089-7091.

51. Nasmith, P. E., G. B. Mills, and S. Grinstein. 1989. Guanine nucleotides induce tyrosine phosphorylation and activation of the respiratory burst in neutrophils. Biochem. J. 257:893-897.

52. Oddie, K. M., J. S. Litz, J. C. Balserak, D. M. Payne, C. E. Creutz, and S. J. Parsons. 1989. Modulation of pp60 ${ }^{c-s r c}$ tyrosine kinase activity during secretion in stimulated bovine adrenal chromaffin cells. J. Neurosci. Res. 24:38-48.

53. Paris, S., and J. Pouyssegur. 1987. Further evidence for a phospholipase C-coupled G-protein in hamster fibroblasts. J. Biol. Chem. 262:1970-1976.

54. Patschinsky, T., T. Hunter, and B. M. Sefton. 1986. Phosphorylation of the transforming protein of Rous sarcoma virus: direct demonstration of phosphorylation of serine 17 and identification of an additional site of tyrosine phosphorylation in $\mathrm{p} 60^{\mathrm{v}-\mathrm{src}}$ of Prague sarcoma virus. J. Virol. 59:73-81.

55. Payet, N., Y. Deziel, and J.-G. Lehoux. 1984. Vasopressin: a potent growth factor in adrenal glomerulosa cells in culture. J. Steroid Biochem. 20:449-454.

56. Rossomando, A. J., D. M. Payne, M. J. Weber, and T. W. Sturgill. 1989. Evidence that pp42, a major tyrosine kinase target protein, is a mitogen-activated serine/threonine protein kinase. Proc. Natl. Acad. Sci. USA 86:6940-6943.

57. Rozengurt, E., A. Legg, and P. Pettican. 1979. Vasopressin stimulation of mouse 3T3 cell growth. Proc. Natl. Acad. Sci. USA 76:1284-1287.

58. Savage, C. R., and S. Cohen. 1972. Epidermal growth factor and a new derivative. J. Biol. Chem. 247:7609-7611.

59. Schelling, P., D. Ganten, G. Speck, and H. Fischer. 1979. Effects of angiotensin II and angiotensin II antagonist saralasin on cell growth and renin in 3T3 and SV3T3 cells. J. Cell. Physiol. 98:503-514.

60. Scott-Burden, T., T. J. Resink, U. Baur, M. Burgin, and F. R. Buhler. 1988. Amiloride sensitive activation of $S_{6}$ kinase by angiotensin II in cultured vascular smooth muscle cells. Biochem. Biophys. Res. Commun. 151:583-589.

61. Sherline, P., and R. Mascardo. 1984. Catecholamines are mitogenic in 3T3 and bovine aortic endothelial cells. J. Clin. Invest. 74:483-487.

62. Sorge, L. K., B. T. Levy, and P. F. Maness. 1984. pp60 $60^{\mathrm{c}-s r c}$ is developmentally regulated in the neural retina. Cell 36:249-257.

63. Stachowiak, M. K., H. K. Jiang, A. M. Poisner, R. K. Tuominen, and J.-S. Hong. 1990. Short and long term regulation of catecholamine biosynthetic enzymes by angiotensin in cultured adrenal medullary cells. J. Biol. Chem. 265:4694-4702.

64. Stratton, K. R., P. F. Worley, R. L. Huganir, and J. M. Baraban. 1989. Muscarinic agonists and phorbol esters increase tyrosine phosphorylation of a 40-kilodalton protein in hippocampal slices. Proc. Natl. Acad. Sci. USA 86:2498-2501.

65. Takemura, H., A. R. Hughes, O. Thastrup, and J. W. Putney. 1989. Activation of calcium entry by the tumor promoter thapsigargin in parotid acinar cells. J. Biol. Chem. 264:1226612271.
66. Tamura, S., T. A. Brown, J. H. Whipple, Y. Fujita-Yamaguchi, R. E. Dubler, K. Cheng, and J. Larner. 1984. A novel mechanism for the insulin-like effect of vanadate on glycogen synthase in rat adipocytes. J. Biol. Chem. 259:6650-6658.

67. Thastrup, O., A. P. Dawson, O. Scharff, B. Foder, P. J. Cullen, B. K. Drobak, P. J. Bjerrum, S. B. Christensen, and M. R. Hanley. 1989. Thapsigargin, a novel molecular probe for studying intracellular calcium release and storage. Agents Actions 27:17-23.

68. Thastrup, O., B. Foder, and O. Scharff. 1987. The calcium mobilizing and tumor promoting agent, thapsigargin elevates the platelet cytoplasmic free calcium concentration to a higher steady state level, a possible mechanism of action for the tumor promotion. Biochem. Biophys. Res. Commun. 142:654-660.

69. Thom, R. E., and J. E. Casnellie. 1989. Pertussis toxin activates protein kinase $\mathrm{C}$ and a tyrosine protein kinase in the human $\mathrm{T}$ cell line Jurkat. FEBS Lett. 244:181-184.

70. Tonks, N. K., and H. Charbonneau. 1989. Protein tyrosine dephosphorylation and signal transduction. Trends Biochem. Sci. 14:497-500.

71. Tsao, M.-S., H. S. Earp, and J. W. Grisham. 1986. The effects of epidermal growth factor and the state of confluence on enzymatic activities of cultured rat epithelial cells. J. Cell. Physiol. 126:167-173.

72. Tsien, R. Y. 1980. New calcium indicators and buffers with high selectivity against magnesium and protons: design, synthesis, and properties of prototype structures. Biochemistry 19:23962404

73. Tsien, R. Y. 1981. A non-disruptive technique for loading calcium buffers and indicators into cells. Nature (London) 290:527-528.

74. Tsuda, T., Y. Hamamori, Y. Fukumoto, K. Kaibuchi, and Y. Takai. 1986. Epidermal growth factor increases c-myc mRNA without eliciting phosphoinositide turnover, protein kinase $\mathrm{C}$ activation, or calcium ion mobilization in Swiss 3T3 fibroblasts. J. Biochem. 100:1631-1635.

75. Ullrich, A., J. R. Bell, E. Y. Chen, R. Herrera, L. M. Petruzzelli, T. J. Dull, A. Gray, L. Coussens, Y.-C. Liao, M. Tsubokawa, A. Mason, P. H. Seeburg, C. Grunfeld, O. M. Rosen, and J. Ramachandran. 1985. Human insulin receptor and its relationship to the tyrosine kinase family of oncogenes. Nature (London) 313:756-761.

76. Ullrich, A., and J. Schlessinger. 1990. Signal transduction by receptors with tyrosine kinase activity. Cell 61:203-212.

77. Wong, S. T., L. F. Winchell, B. K. McCune, H. S. Earp, J. Teixido, J. Massague, B. Herman, and D. C. Lee. 1989. The TGF $\alpha$ precursor expressed on the cell surface binds to the EGF receptor on adjacent cells, leading to signal transduction. Cell 56:495-506.

78. Yarden, Y., and A. Ullrich. 1988. Growth factor receptor tyrosine kinases. Annu. Rev. Biochem. 57:443-478.

79. Zachary, I., P. J. Woll, and E. Rozengurt. 1987. A role for neuropeptides in the control of cell proliferation. Dev. Biol. 124:295-308.

80. Zagari, M., M. Stephens, H. S. Earp, and B. Herman. 1989 Relationship of cytosolic ion fluxes and protein kinase $\mathrm{C}$ activation to platelet-derived growth factor induced competence and growth in BALB/c-3T3 cells. J. Cell. Physiol. 139:167-174. 